American University Washington College of Law

Digital Commons @ American University Washington College of

Law

Articles in Law Reviews \& Other Academic Journals

Scholarship \& Research

6-11-2021

Protecting and Fostering Online Platform Competition: The Role of Antitrust Law

Jonathan Baker

Follow this and additional works at: https://digitalcommons.wcl.american.edu/facsch_lawrev

Part of the Antitrust and Trade Regulation Commons 


\title{
PROTECTING AND FOSTERING ONLINE PLATFORM COMPETITION: THE ROLE OF ANTITRUST LAW
}

\author{
Fonathan B. Baker*
}

This essay provides a perspective on the role of antitrust law in protecting and fostering competition in the digital economy, with particular attention to online platforms. It highlights the danger of anticompetitive exclusionary conduct by dominant online platforms and describes ways that antitrust law can challenge and deter such conduct. The essay also identifies a number of difficulties that U.S. courts and enforcers face in challenging harmful exclusionary conduct by dominant platforms, and discusses some ways that regulation can supplement antitrust law in fostering competition.

Many of these themes are pursued in more detail in my book, The Antitrust Paradigm, ${ }^{1}$ though in some places, this discussion goes beyond the book. Although some of the problems discussed here are distinctive to the United States, others can impede enforcement in all jurisdictions.

These issues are increasingly salient in the United States. The House Judiciary Committee's antitrust subcommittee recently conducted a high-profile investigation into competition in digital markets. The majority (Democratic) issued a staff report at the end of the investigation that targeted Amazon, Apple, Facebook, and Google - the four digital platforms it called dominant. The report detailed platform conduct said to exploit platform users and discourage platform competition. ${ }^{2}$ It identified a number of possible legislative remedies to combat the problem, including changes to the antitrust laws and new regulatory rules. Concerns about the four platforms were bipartisan: all but one of the subcommittee members in the minority (Republicans) endorsed the description of the harmful conduct of large technology firms in digital markets, though they took issue with some of the legislative recommendations. ${ }^{3}$ Against

\footnotetext{
* Research Professor of Law, American University Washington College of Law. The author is grateful to Andy Gavil and Steve Salop.

1 Jonathan B. Baker, The Antitrust Paradigm (2019).

2 Majority Staff of S. Comm. on Antitrust, Commercial and Admin. Law H. Committee on THE Judiciary, 1156th Cong., Investigation of Competition in Digital Markets, Majority StafF ReP. AND Recommendations (2020).

${ }^{3}$ Rep. Ken Buck, S. Comm. on Antitrust, Commercial and Admin. Law, H. Committee on THE Judiciary, 1156Th Cong., The Third WAy (2020).
} 
this background, it is helpful to review how dominant online platforms can harm competition through exclusionary conduct, and identify some of the challenges that arise in demonstrating and remedying those problems.

\section{ECONOMICS}

Online platforms serve an important economic function: they facilitate economic interactions among end users and competition among sellers who connect to the platform. There are many varieties and many familiar examples. Amazon's Marketplace connects shoppers and manufacturers, and facilitates competition among manufacturers. Apple and Google (Android) have app stores that connect applications developers and smartphone or tablet users, and facilitate competition among developers. Social media platforms (for example, Facebook and LinkedIn) connect members to one another, permit advertisers and advocates to reach members, and facilitate competition among advertisers and advocates. Search engines (for example, Google and Microsoft (Bing)) allow advertisers to interact with consumers and to compete with other advertisers. Other online platforms include payment systems (for example, Visa and MasterCard), broadband providers, and restaurant reservation services (for example, OpenTable).

Online platform markets often tend toward having a dominant platform. One reason involves network effects: as platforms gain more users, they often become more valuable to users, which may allow them to attract even more users. Network effects may be direct, as with social media and communications platforms, or they may be indirect, as with shopping platforms. More shopping platform consumers make the platform more attractive to sellers, and vice versa.

Scale economies in supply also may lead to a dominant platform. The fixed costs of platform operation may be large, while the costs of adding additional users may be small. Or important costs (for example, for product delivery) may decrease as the number of users grows.

The emergence of a dominant platform is not inevitable. In some markets, network effects and user switching costs may be naturally low or largely exhausted at a scale that allows multiple platforms to be viable. User control over data, as with portability, can reduce switching costs. Switching costs can be low in markets where users value multihoming (use of multiple platforms), and it is not prevented by the platform's architecture or terms of use. Interoperability may permit multiple platforms to share network effect benefits. When users vary in their preferences for platform features, multiple differentiated platforms may successfully co-exist.

In markets with a dominant online platform, the most important competition may come from potential rivals and fringe competitors. If platform users are willing and able to switch to a rival with a superior product, dominance 
can erode. The market could even tip to the rival: as the rival benefits from increased network effects, it may attract even more users and it may become dominant. In some cases, even the mere possibility that a fringe rival or entrant could expand and replace the incumbent could constrain a dominant platform's exercise of market power to some extent.

Exclusionary conduct by a dominant platform can suppress this key competitive force. Think, hypothetically, for example, of Google excluding Bing, Amazon excluding Walmart, or Facebook excluding Snap (Snapchat). Here, "exclusion" means disadvantaging and possibly marginalizing rivals, in addition to possibly forcing them to exit or preventing their entry. The dominant platform also may find ways to exclude nascent or potential platform rivals, not just current rivals, by impeding entry and expansion.

At the same time, exclusion of competitors does not necessarily add up to harm to competition. If one pizza parlor sets fire to a neighboring store, and there are a number of other pizza stores in the neighborhood, the local pizza market would likely remain competitive so the exclusionary conduct is most likely just a business tort, not also an antitrust violation. But when a market has a dominant firm, the loss of any rival — even a small rival or a potential one-can often reasonably be expected to reduce the odds that competition will emerge. Under such circumstances, harm to a competitor can be expected to create a material risk of harm to competition.

Dominant online platforms can adopt a number of strategies to exclude actual or potential platform rivals. ${ }^{4}$ One possible exclusionary strategy involves exclusive dealing: a dominant platform could simply forbid its sell-side users (for example, manufacturers or advertisers) from patronizing a rival platform. Platform most favored nations (price parity) provisions may have a similar exclusionary effect when the rival platform's strategy is predicated on offering low seller prices. Or the platform may make it more difficult for rivals to attract users by increasing customer switching costs, for example, by introducing membership fees (perhaps combined with lower usage prices) or by preventing interoperability or multihoming.

The anticompetitive conduct in several prominent predigital examples of exclusionary platform conduct can be thought of as locking-in users by preventing multihoming or, alternatively, as exclusive dealing: the Lorain fournal newspaper excluded a local radio station entrant by declining to accept advertisements from merchants that advertised on the radio station; ${ }^{5}$ the FTD (telephone) flower delivery network impeded the development of rival networks by preventing its florists from signing up with other networks; ${ }^{6}$

${ }^{4}$ These and other exclusionary strategies that dominant platforms could employ are discussed in more detail in chapter 7 of The Antitrust Paradigm.

${ }^{5}$ Lorain Journal Co. v. United States, 342 U.S. 143 (1951).

${ }^{6}$ See American Floral Services, Inc. v. Florists' Transworld Delivery Ass'n, 633 F. Supp. 201, 204 n.5 (N.D. Ill. 1986) (citing United States v. Florist's Telegraph Delivery Ass'n, 1956 Trade Cas. $(\mathrm{CCH})$ - 68,367 (E.D.Mich.1956)); United States v. Florist's Telegraph Delivery Ass'n 
and Mastercard and Visa prevented member banks from issuing credit cards offered by other payment systems, including American Express and Discover. ${ }^{7}$

In the digital world, dominant online platforms may adopt similar strategies to exclude platform rivals. They may also exclude platform rivals by foreclosing their access to data generated by users. With less data, or less data of certain types, an entrant or rival may have less ability to exploit network effects or obtain scale economies. In addition, dominant online platforms can exclude by acquiring potential rivals, whether nascent platform competitors or sellers of complementary (or vertically related) services that could become rivals. For example, some have suggested that Facebook harmed social media competition by acquiring Instagram, or Google maintained its advertising dominance or achieved dominance in advertising technology by acquiring DoubleClick.

When online platform owners also use the platform, moreover, they can employ exclusionary strategies against rival end users. It is not uncommon for platform owners to be users as well. Amazon runs a marketplace on which it sells private label products. Google has a search engine and also provides shopping services such as flight information. Apple runs an app store and offers services similar to those provided by some apps. For example, it offers Spotify's music application as well as its own music application.

A platform that is also a user can impede entry or expansion by rival users through input or customer foreclosure-and it may have the incentive as well as the ability to do so by virtue of the fact that it is both user and provider. It could, for example, bias search results to favor its own products or to disfavor rivals' products, or refuse to link to rival users. It could also target rival users for product design or price competition, perhaps using its privileged access to customer data when rival users have less access to data so they cannot easily fight back. These possibilities do not exhaust the ways a dominant platform can exclude rival platforms or rival users, but they do illustrate economic incentives and mechanisms that could lead to such reductions in competition.

\section{ANTITRUST LAW AND POLICY}

Antitrust law and policy seek to deter and remedy conduct that harms competition, including exclusionary conduct by dominant platforms. Such conduct can be reached by U.S. antitrust law if undertaken by agreement, ${ }^{8}$ if undertaken by a dominant firm (one with what the law terms "monopoly" power) or by a large firm with a dangerous probability of achieving monopoly

1996 Trade Cas. (CCH) $\uparrow 71,394$ (E.D.Mich.1990); U.S. Justice Department Antitrust Division, "Justice Department Settles Charges Against FTD, The Leading Flowers-by-Wire Company, for Violating 1990 Consent Decree," press release, August 2, 1995.

${ }^{7}$ United States v. Visa, 344 F.3d 229 (2d Cir. 2003).

${ }^{8} 15$ U.S.C. $\$ 1$. Invitations to collude cannot be reached under Section 1 of the Sherman Act, but the F.T.C. challenges them under Section 5 of the FTC Act. 15 U.S.C. $₫ 45$. 
power, ${ }^{9}$ if undertaken through exclusive dealing or tying in the sale of goods, ${ }^{10}$ or if undertaken through acquisition or merger. ${ }^{11}$

The evidentiary burdens of establishing competitive harm from exclusionary conduct can be demanding, however. Exclusionary unilateral conduct cannot be challenged under Section 1 of the Sherman Act, which requires proof of an agreement. If that conduct is undertaken by a firm with a share too low to prove monopoly power or dangerous probability of successful monopolization and direct proof is unavailable, ${ }^{12}$ the conduct cannot be challenged under Section 2 of the Sherman Act. ${ }^{13}$

Beyond satisfying the agreement prerequisite for Section 1 liability, or the monopoly power (or dangerous probability of success) prerequisite for Section 2 liability, the plaintiff must demonstrate that the exclusionary conduct harms competition. ${ }^{14}$ Yet, a variety of judicially created hurdles may impede doing so in meritorious cases. Courts have treated exclusionary nonprice vertical conduct as presumptively procompetitive, even in settings such as oligopoly markets and markets with dominant firms where it is well-established that vertical restraints can harm competition. ${ }^{15}$ In some cases, courts have declined to condemn exclusionary conduct that harms competition on balance if the conduct benefits competition in any way, or plausibly could do so, regardless of the magnitude of the competitive benefit. ${ }^{16}$ Importantly for dominant platforms, some commentators interpret the Supreme Court as suggesting that the prohibition on monopolization would not reach unilateral refusals to deal

915 U.S.C. $\$ 2$. Section 2 of the Sherman Act also prohibits conspiracies to monopolize.

${ }^{10} 15$ U.S.C. $\$ 14$.

1115 U.S.C. $\$ 18$.

${ }^{12}$ Courts often require a $70 \%$ share for finding monopoly power in a monopolization case, and a $50 \%$ share with a prospect of achieving a monopoly share for finding dangerous probability of success in an attempted monopolization case. ANDREW I Gavil, William E. Kovacic, Jonathan B. Baker \& Joshua D. Wright, Antitrust LaW in Perspective: Cases, Concepts and Problems in Competition Policy 640 (3d ed. 2017). While monopoly power and dangerous probability of success are almost always demonstrated with proof of market share, it is also possible to make these showings with direct evidence. Re/Max Int'l, Inc. v. Realty One, Inc., 173 F.3d 995 (6th Cir 1999).

${ }^{13}$ See Spectrum Sports, Inc. v. McQuillan, 506 U.S. 447, 456, 459 (1993); cf. Copperweld Corp. v. Independence Tube Corp., 476 U.S. 752, 767-68 (1984). See also Verizon Communications Inc. v. Law Offices of Curtis V. Trinko, LLP, 540 U.S. 398, 415 n.4 (2004).

${ }^{14}$ In its influential decision in United States v. Microsoft Corp., 253 F.3d 34 (D.C. Cir. 2001), the D.C. Circuit reviewed the exclusionary conduct element of the monopolization offense using a burden-shifting framework similar to the approach applied to evaluate the reasonableness of conduct under Sherman Act Section 1. A similar reasonableness approach is used today to evaluate exclusionary conduct challenged as exclusive dealing under the Sherman Act or the Clayton Act, challenged as a vertical agreement, regardless of whether it involves price or nonprice terms, or challenged as tying or an exclusionary group boycott if a per se rule does not apply.

15 See Andrew I Gavil, William E. Kovacic, Jonathan B. Baker \& Joshua D. Wright, Antitrust Law in Perspective: Cases, Concepts and Problems in Competition Policy 917-19 (3d ed. 2017).

${ }^{16}$ E.g., Novell, Inc. v. Microsoft Corp., 731 F.3d 1064, 1072, 1075 (10th Cir. 2013) (Gorsuch, J.). 
with a rival by a vertically integrated platform, that is, one that is also a supplier (or seller of a complementary product), unless the platform had previously supplied the rival. ${ }^{17}$ In order to adopt this suggestion as holding, however, the Court would need to overrule Lorain fournal ${ }^{18}$ — a platform monopolization decision predicated on a unilateral refusal to deal that was later endorsed by both Robert Bork and the modern Supreme Court. ${ }^{19}$

The Supreme Court's American Express decision may create additional hurdles for plaintiffs bringing meritorious exclusion cases against dominant platforms. ${ }^{20}$ It suggests that market definition is required, and direct evidence is insufficient for proving market power, in exclusionary vertical restraints cases (conduct involving an agreement between a firm and its suppliers or distributors). ${ }^{21}$ If this is how American Express is interpreted by lower courts, it may require fact-finders to analyze, for example, the extent to which different social media compete for attention, online advertisers compete with cable and print ads, or general-purpose online retailers compete with brick and mortar retailers or specialized online retailers-even when direct evidence would make it possible to demonstrate competitive harm or market power reliably without making an inference from market shares, and thus without reaching potentially difficult market definition questions. American Express may also require courts to analyze the competitive effects of conduct by transaction platforms within cluster markets encompassing end users on both sides ${ }^{22}$ - which can create confusion when evaluating competitive harms. ${ }^{23}$

Beyond these legal issues, there are a number of practical impediments to bringing meritorious exclusion cases against dominant platforms. The most important problems impede challenges to the exclusion of nascent rivals and

${ }^{17}$ See Verizon Communications Inc. v. Law Offices of Curtis V. Trinko, LLP, 540 U.S. 398, 409 (2004) (describing Aspen Skiing Co. v. Aspen Highlands Skiing Corp., 472 U.S. 585 (1983) as creating a "limited exception" to the right of a firm to refuse to deal with a rival and as "at or near the outer boundary of $₫ 2$ liability"). Aspen may also support a challenge to unilateral refusals to deal with a rival by a vertically integrated platform that excludes rivals while voluntarily dealing with non-rivals. The defendant in that case declined to sell to its rival, even at a retail price, while continuing to sell to consumers (skiers and tour operators).

${ }^{18}$ Lorain Journal Co. v. United States, 342 U.S. 143 (1951).

${ }^{19}$ Robert Bork, The Antitrust Paradox 344-46 (1978); Aspen Skiing Co. v. Aspen Highlands Skiing Corp., 472 U.S. 585, 603 (1983) ("The qualification on the right of a monopolist to deal with whom he pleases is not so narrow that it encompasses no more than the circumstances of Lorain Journal.").

${ }^{20}$ Ohio v. American Express Co., 138 S. Ct. 2274 (2018).

${ }^{21} 138$ S.Ct. at 2285 n.7. American Express was brought under Section 1 of the Sherman Act, which is concerned with unreasonable agreements.

${ }^{22}$ The Court defined a cluster market encompassing both sides of a two-sided platform in a narrow setting: when users on different sides are matched in a single, simultaneous transaction, $138 \mathrm{~S}$. Ct. at 2286, and when network effects are so strong as to make it impossible for firms other than transaction platforms to compete on either side. $138 \mathrm{~S}$. Ct. at 2287.

${ }^{23}$ See Jonathan B. Baker, Market Definition: An Analytical Overview, 74 Antitrust L. J. 129, 134 \& 134 n.30 (2007). 
potential entrants. The antitrust laws reach such conduct, ${ }^{24}$ but it can be difficult for governmental or private plaintiffs to prove that nascent or potential rivals are a competitive threat, even when that is in fact the case, simply because those firms, by definition, lack a track record showing what they can do; the proof may end up turning more on capabilities than on past results. When exclusionary conduct deters potential rivals from even attempting entry, an antitrust case may be difficult to prove because it may be hard to tell whether the excluded firm is truly a potential entrant that could become a viable and effective competitor. These problems, particularly when exacerbated by judicial delays, mean that a range of damaging exclusionary conduct may not be deterred and that courts may be unable to restore competition (as by preserving the excluded firms).

In addition, foreclosed rivals, whether actual or potential competitors, may have little incentive themselves to challenge the exclusionary conduct of wellheeled platforms. Even where its case is strong, moreover, a rival may do better accepting a large financial settlement that leaves the platform's monopoly power intact, rather than litigating to create competition. ${ }^{25}$

When a potential entrant is acquired, it can also be difficult to show that competition is harmed. Courts now require that the plaintiff, which is usually a government agency, show that the potential entrant would have otherwise entered the market rapidly and been viable, and that there are few other likely potential entrants. ${ }^{26}$ Evidence of competitive harm may be hard to come by because a potential entrant that has been acquired for a high price would have little incentive to support the government's challenge.

Meritorious exclusion cases against dominant platforms are also impeded by the erroneous assumptions that some courts accept, at times encouraged by defendants and non-interventionist commentators. ${ }^{27}$ Some erroneous assumptions are about markets. It is wrong to suppose, as a general rule, that monopolies lead to more innovation than competitive markets, that forcing

${ }^{24}$ United States v. Microsoft Corp., 253 F.3d 34, 79 (D.C. Cir. 2001).

25 Cf. FTC v. Actavis, Inc., 133 S.Ct. 2223 (2013).

${ }^{26}$ FTC v. Steris Corp., 133 F. Supp. 3d 962 (N.D. Ohio 2015). The potential competition jurisprudence addresses the loss through merger of anticipated rivalry in current products, not a loss of rivalry in innovation or future products. That is, the case law on potential competition focuses on acquisitions of firms with concrete plans to enter soon in current product markets; these are acquisitions of firms that already constrain the conduct of incumbents. That case law does not preclude a challenge under Clayton Act $₫ 7$ to the acquisition of a firm that is considering entry and making investments that would facilitate entry, but without concrete plans to enter, or to the acquisition of a firm with capabilities to enter but not taking steps to do so. Section 7 of the Clayton Act reaches all acquisitions that may harm competition, including the latter cases. C. Scott Hemphill \& Tim Wu, Nascent Competitors,-U. PENN. L. REV.-(2020 forthcoming).

27 These erroneous assumptions are discussed in Chapter 5 of The Antitrust Paradigm, with the exception of the assumption about the consequences of forcing a monopoly platform to admit a rival user, which is addressed in Steven C. Salop and R. Craig Romaine, Preserving Monopoly: Economic Analysis, Legal Standards and Microsoft, 7 GEORGE MASON L.R. 617 (1999). 
a monopoly platform to admit rival users will reduce innovation by both the monopolist and its rivals, that the exercise of market power rapidly self-corrects through entry, or that business practices prevalent in competitive markets, such as vertical restraints, are unlikely to harm competition when employed in oligopoly markets or markets with a dominant firm.

Other erroneous assumptions are about courts. It is also wrong to suppose, in general, that courts cannot tell whether exclusionary conduct harms competition or promotes it, that erroneous judicial precedents are more durable than the exercise of market power, or that the litigation process is manipulated by complaining competitors.

\section{REGULATION}

Most discussions of competition policy, including my book, The Antitrust Paradigm, are concerned primarily with ways the courts can and should apply the antitrust laws to address and deter competitive problems - including anticompetitive exclusionary conduct by dominant online platforms. Yet, other public policy responses are also available. Congress could amend the antitrust laws to address impediments to the success of meritorious challenges to exclusionary conduct. ${ }^{28}$ In addition, regulation may usefully supplement antitrust in fostering platform competition.

Regulation has a number of general advantages and disadvantages. On the one hand, it can be a cost-effective way of addressing a market failure-such as externalities, providing public goods (which may include competition), or overcoming problems associated with moral hazard or adverse selectionparticularly when Coasian bargaining among private actors would be a costly or inadequate substitute. On the other hand, regulation has at times suffered from ineffectiveness, delay, or misuse (as when regulators are captured by regulated industries). In addition, over-regulation can create social costs by impeding efficiency-enhancing firm conduct, including innovative effort and productivity-enhancing activities, and by entrenching existing market structures and business models.

Regulation can supplement antitrust law by fostering competition among dominant online platforms. When used for this purpose, regulation has a number of advantages. Regulators typically have expertise that generalist courts enforcing the antitrust laws do not. For example, agencies, such as FERC and the FCC, have developed and enforced interoperability and nondiscrimination requirements, which some have suggested for encouraging competition among

${ }^{28}$ For examples, see Joint Response to the House Judiciary Committee on the State of Antitrust Law and Implications for Protecting Competition in Digital Markets, Testimony of Michael Kades before the Subcommittee on Antitrust, Commercial, and Administrative Law of the House Committee on the Judiciary (October 1, 2020) (Appendix A), https://equitablegrowth.org/testimony-by-michael-kades-before-the-subcommi ttee-on-antitrust-commercial-and-administrative-law-on-digital-markets/ 
or on online platforms. Regulation may also reduce delays. If remedies for competition problems such as platform interoperability, data portability, or open standards are desirable, ${ }^{29}$ regulators may be able to impose and enforce them more quickly than courts. Regulators relying on rulemaking may be able to alter practices across an industry more easily than can courts relying on case-by-case adjudication. ${ }^{30}$ Regulation may also reach conduct that antitrust may not reach easily, such as dominant platform conduct that chills potential competition and innovation by firms that are not yet a success or have not yet been imagined, or government-imposed restrictions on entry that impede competition.

Finally, regulatory solutions may usefully supplement antitrust remedies for exclusionary conduct by dominant platforms when the conduct creates important noncompetition problems that fostering platform competition would not fully solve, such as protecting privacy or preventing discrimination or other harms to vulnerable consumers. Similarly, a regulator attuned to consumer protection issues may do better than a court in developing means of promoting competition through data portability that does not undermine user privacy.

\section{CONCLUSION}

Deterring and remedying anticompetitive exclusionary conduct by dominant online platforms creates an important challenge for competition policy today. Competition authorities in Europe have taken the lead in evaluating the behavior of large online platforms, and the U.S. antitrust agencies have recently begun to do the same. Antitrust law, by itself or supplemented by regulation, is a critical tool for fostering platform competition.

${ }^{29}$ See Unlocking Digital Competition, Report of the Digital Competition Expert Panel (March 13, 2019), available at https://www.gov.uk/government/publications/unlocking-digi tal-competition-report-of-the-digital-competition-expert-panel; Economyand Market Structure, Report of the Market Structure and Antitrust Subcommittee, Committee for the Study of Digital Platforms, George J. Stigler Center for the Study of the Economy and the State, The University of Chicago Booth School of Business (July 1, 2019), available at https://research.chicagobooth.edu/stigler/events/single-events/antitrust-competition-confere nce/digital-platforms-committee; Jacques Crémer, Yves-Alexandre de Montjoye, and Heike Schweitzer, Competition Policy for the Digital Era (European Commission 2019), available at https://ec.europa.eu/competition/publications/reports_en.html; Harold Feld, The Case for the Digital Platform Act (2019), available at https://www.publicknowledge.org/documents/the-ca se-for-the-digital-platform-act/.

${ }^{30}$ On the Federal Trade Commission's competition rulemaking authority, see Jonathan B. Baker, Two Sherman Act Section 1 Dilemmas: Parallel Pricing, the Oligopoly Problem, and Contemporary Economic Theory, 38 Antitrust Bull. 143, 207-19 (1993); Rohit Chopra \& Lina M. Khan, The Case for "Unfair Methods of Competition" Rulemaking, 87 U. CHI. L. REv. 357 (2020); C. Scott Hemphill, An Aggregate Approach to Antitrust: Using New Data and Rulemaking to Preserve Drug Competition, 109 Colum. L. Rev. 629, 673-82 (2009). 